\title{
The Impact of Sustainable Certification on Financial and Market Performance: Evidence from Indonesian Palm Oil Companies
}

\author{
Arif Imam Suroso ${ }^{1 *}$, Hansen Tandra ${ }^{2}$, Indra Wahyudi ${ }^{1}$ \\ ${ }^{1}$ School of Business, IPB University, Bogor 16128, Indonesia \\ ${ }^{2}$ Department of Resources and Environmental Economics, IPB University, Bogor 16680, Indonesia
}

Corresponding Author Email: arifimamsuroso@apps.ipb.ac.id

https://doi.org/10.18280/ijsdp.160810

Received: 10 September 2021

Accepted: 19 October 2021

\section{Keywords:}

business analytic, firm performance, palm oil, sustainable certification

\begin{abstract}
The palm oil industry is a strategic sector that plays an important role for national economics Although the palm oil industry's role and contribution are high, land clearing and operation are often associated with environmental and social issues. The sustainable certification was then developed to ensure that palm oil companies can continue to operate without involving environmental and social deprivation. The previous research related to the impact of a sustainable certification found several positive and negative impacts on palm oil companies' performance in general. Therefore, this study aimed to determine the impact of sustainable certification on Indonesia's palm oil companies' financial and market performance. This research focused on 14 palm oil companies in Indonesia that went public with an observation year between 2014 and 2019. Analysis through panel regression found that sustainable certification has no impact on Indonesia's palm oil companies' financial and market performance. The study could be a recommendation and justification for palm oil companies for consider to take a sustainable certification.
\end{abstract}

\section{INTRODUCTION}

The palm oil industry has an important role in the Indonesia economy. The contribution of palm oil exports reached 30.3 million tonnes in 2018 [1]. Agroindustry is believed to be the prominent sector which can run the agribusiness system well [2]. The Indonesian palm oil industry is very competitive at the company level and the global level $[3,4]$. The development of palm oil plantations can be used as an effort by local governments to generate foreign exchange, expand job opportunities, and improve local welfare $[5,6]$. The palm oil plantations are a source of employment that can increase the living standard and household income of Indonesia's palm oil farmers [7].

Although palm oil plays an important role in the national economy, issues related to palm oil production sustainability have created polarization in recent years for policymakers and companies [8]. The palm oil industry's opening is often a matter of debate in every developing country, including Indonesia. The debates that often arise are environmental problems such as air pollution, land displacement, and deforestation, which have implications for reducing the world's biodiversity $[9,10]$. Apart from environmental issues, palm oil is considered to cause social conflicts in the community [11]. There is pressure from various authorities regarding the need for sustainability standards on palm oil plantation companies due to the negative issues [12]. As a result, there are concerns on the consumers that indirectly affect their purchasing preferences [13]. In addressing this issue, sustainable certification was developed through the Roundtable on Sustainable Palm Oil (RSPO) to implement global standards for sustainable palm oil.

The implementation of sustainable certification is suspected to be detrimental to the performance of palm oil companies. In general, there is no difference in financial performance for companies that implement sustainable development [14]. Sustainable certification for exports does not improve the profitability performance of palm oil companies, especially in Malaysia [15]. As a result, companies that adopt RSPO have the potential to withdraw from RSPO certification and membership either temporarily or permanently. However, other studies suggest the opposite effect. Palm oil plantation that is RSPO certified can have a profitability advantage and increase sales to smallholders compared to palm oil plantations that are not certified [16]. The production certified as a sustainable aspect is required by several palm oilimporting countries, so that certification allows companies to enter new market shares [17].

Palm oil plantation companies in Indonesia need to be observed because Indonesia is one of the main producers of palm oil in the world. Several oil palm companies in Indonesia have adopted RSPO certification for its operations. However, further investigation is needed to assess the impact of RSPO sustainability certification on Indonesia's palm oil companies' performance. This study focuses on the impact of certification on the financial performance and market performance of palm oil companies. Aside from sustainable certification, this study also presents several independent variables that affect Indonesia's palm oil firm performance. The limitation of this study is exploration the RSPO certification on firm performance based on financial and market performance. 


\section{METHODOLOGY}

Firm performance can be measured from the perspective of financial performance and market performance [18, 19]. Various factors are considered to affect the company's performance both from financial and non-financial factors [20, 21]. RSPO is a non-profit association that brings together stakeholders from seven palm oil industry sectors, namely palm oil producers, palm oil traders and processors, consumer goods producers, retailers, banking and investors, environmental conservation NGOs, and social sector NGOs. RSPO develops sustainable standards based on global certification for palm oil to ensure that palm oil companies do not sacrifice environmental and social aspects but care about environmental and social aspects that have been integrated with profit gain or the economy [22].

Participation in sustainable certification is estimated to affect palm oil companies' performance. Sustainable certification is found to benefit the financial and non-financial performance of companies in various sectors [23]. Additionally, it is found that sustainable certification has several beneficial impacts on companies regarding stock prices [24]. Previous research has investigated the performance of palm oil companies in Malaysia and found a positive effect of sustainable certification on palm oil companies' profitability performance [25]. Other studies have found that sustainable certification for exports has no impact on palm oil companies' operational performance in Malaysia [15]. The timing in adopting RSPO certification influences the profitability of the palm oil companies [26]. This study combines some literature related to other factors that affect the performance of palm oil companies. Factors come from the palm oil company's internal conditions, which are financial and non-financial aspect. Here are some other factors based on internal firm are used in this study as determinants of firm performance:

- Liquidity. Liquidity is a financial ratio that measures a company's ability to meet its financial obligations that must be paid off immediately. The higher the company's liquidity level, the greater its ability to meet the short-term debt. Companies that are successful in overcoming shortterm debt are indicated to have good performance. Previous research states that the liquidity variable can affect firm performance [27, 28]. Moreover, another research has also found that liquidity affects palm oil companies' performance from an operational and market perspective from Price to Earning Ratio (PER) indicator [29].

- Capital Structure. Capital structure is a specific combination of debt and capital used by a company to finance its operations. Capital structure can also be defined as an asset that comes from debt and firm's capital [30]. Agency theory states that the higher the capital owned, the lower the agency costs, which have implications for improving the firm performance [31]. The capital structure is known to have a positive impact on the performance of non-financial companies in Thailand [32]. On the other hand, it is also found that the capital structure, which is proxied by the debt ratio, has a negative impact on firm performance $[33,34]$.

- Dividend Policy. A dividend is a company policy to provide a portion of profit to shareholders. Signaling theory explains that dividend policy is a form of communication to investors so that there is information that can be used to assess the stock price of a company [35]. The bird in hand theory states there is a relationship between dividend policy and firm value because the risk of dividends is considerably lower than capital gains [36]. Previous research has also found that there is an impact of dividend policy on firm performance $[37,38]$. It is found that there is an effect of dividend policy on the profitability performance of palm oil companies [39].

- CPO Extraction Rate. CPO extraction is a processing manner from palm fruit bunches to palm oil. The income of palm oil companies in Indonesia is largely dependent on the yield of palm oil. Efficient operational activities can improve firm performance [40]. Thus, the level of CPO extraction from palm oil companies greatly affects the firm's performance. Previous research reported that $\mathrm{CPO}$ extraction affects firm performance [26].

- Firm size. Large companies tend to exhibit higher performance than small ones. This is in line with the risks taken by large companies because they tend to borrow from parties outside the company. This is different from small companies with limited funding sources and uses internal financing because of the high costs and risks [41]. Previous research found that firm size has an impact on company performance $[15,42]$.

- Firm Age. Older companies have more experience dealing with problems, which have implications for improving firm performance [43]. Previous research has shown that there is a negative correlation between age and firm performance [44]. Other previous research findings indicate a negative effect of age on firm performance [45, 46].

The operational definition of the research variables is presented in Table 1. Based on the literature review, the research hypothesis is formulated as follows:

- Hypothesis 1: RSPO certification has a positive impact on the firm's financial and market performance

- Hypothesis 2: Liquidity has a positive impact on the firm's financial and market performance

- Hypothesis 3: The capital structure has a positive impact on the firm's financial and market performance

- Hypothesis 4: Dividend policy has a negative impact on the firm's financial and market performance

- Hypothesis 5: The CPO extraction rate has a positive impact on the firm's financial and market performance.

- Hypothesis 6: The firm's size has a positive impact on the company's financial and market performance.

- Hypothesis 7: The firm's age has a positive impact on the company's financial and market performance

The data in this research came from secondary data. The number of samples in this study was all of the palm oil companies that listed on the Indonesia Stock Exchange. There were 19 registered palm oil companies, but this research only concentrated on 14 public companies. The observation period is between 2014 and 2019. This is due to the limited information obtained from available financial reports. The total data used in the analysis were 84 observations.

The data obtained were analyzed using a panel data regression analysis approach. This approach is used to examine the impact of sustainable certification and other factors that affect Indonesia's palm oil plantation companies' performance. Based on the study variables, two-panel regression equations were built and used to analyze the research objectives. The model to be estimated is as follows: 


$$
\begin{aligned}
\mathrm{Y}_{\mathrm{i}, \mathrm{t}}= & \beta_{0}+\beta_{1} \mathrm{RSPO}_{\mathrm{i}, \mathrm{t}}+\beta_{2} \mathrm{LIQ}_{\mathrm{i}, \mathrm{t}}+\beta_{3} \mathrm{DERi}, \mathrm{t}+\beta_{4} \mathrm{DIVP}_{\mathrm{i}, \mathrm{t}} \\
& +\beta_{5} \mathrm{OER}_{\mathrm{i}, \mathrm{t}}+\beta_{6} \mathrm{SIZE}_{\mathrm{i}, \mathrm{t}}+\beta_{7} \mathrm{AGE}_{\mathrm{i}, \mathrm{t}}+\varepsilon_{\mathrm{i}, \mathrm{t}}
\end{aligned}
$$

where, $\mathrm{Y}$ is the firm performance variable measured by two variables, namely ROE and Tobin's-Q at the company i in year $\mathrm{t}$; $\mathrm{RSPO}_{\mathrm{i}, \mathrm{t}}$ is the company's participation in sustainable certification; $\mathrm{LIQ}_{\mathrm{i}, \mathrm{t}}$ is the current ratio; $\mathrm{DER}_{\mathrm{i}, \mathrm{t}}$ is the ratio of debt to equity; $\mathrm{DIVP}_{\mathrm{i}, \mathrm{t}}$ is dividend policy; $\mathrm{OER}_{\mathrm{i}, \mathrm{t}}$ is extraction rate of $\mathrm{CPO}$; $\mathrm{SIZE}_{\mathrm{i}, \mathrm{t}}$ is firm size; $\mathrm{AGE}_{\mathrm{i}, \mathrm{t}}$ is the age of the company; and $\varepsilon_{\mathrm{i}, \mathrm{t}}$ is the error rate.

\begin{tabular}{|c|c|}
\hline Variable & Definition \\
\hline ROE & $\begin{array}{l}\text { Return on equity, computed by dividing an } \\
\text { annual net income in a firm by the average } \\
\text { of the firm's total equity }\end{array}$ \\
\hline Tobin's-q & $\begin{array}{c}\text { Tobin's-q ratio, computed by dividing a sum } \\
\text { of the market capitalization and total } \\
\text { liabilities by total assets }\end{array}$ \\
\hline RSPO & $\begin{array}{l}\text { A dummy variable which takes the value of } \\
\text { "1" if the firm participate in an RSPO } \\
\text { certification, "0" otherwise }\end{array}$ \\
\hline Liquidity & $\begin{array}{c}\text { The firm's current ratio is calculated as the } \\
\text { ratio of its current assets divided by its } \\
\text { current liabilities }\end{array}$ \\
\hline DER & $\begin{array}{l}\text { The firm's total debt ratio is calculated as the } \\
\text { total debt ratio in its total equity }\end{array}$ \\
\hline Dividend_Policy & $\begin{array}{l}\text { A dummy variable which takes the value of } \\
\text { " } 1 \text { " if the firms undertake a dividend policy } \\
\text { in the observation period, " } 0 \text { " otherwise }\end{array}$ \\
\hline Oil_Extraction & $\begin{array}{c}\text { The CPO extraction rate in the firm's annual } \\
\text { report }\end{array}$ \\
\hline Size & $\begin{array}{c}\text { The natural logarithm of the firm's total } \\
\text { assets }\end{array}$ \\
\hline Age & $\begin{array}{l}\text { The natural logarithm of the firm's age in } \\
\text { the observation periods }\end{array}$ \\
\hline
\end{tabular}

Table 1. Definition of variable operationalization

\section{RESULTS}

Table 2 presents the descriptive statistics of the variables used. Based on this descriptive statistic, the average ROA value of the sample was $5.76 \%$. The identified Tobin's-q mean was 1.18 . There were $63 \%$ of palm oil companies in the study observation period that adopted RSPO certification. Meanwhile, the average liquidity value was 1.33 times. The average DER was $71 \%$. The average number of dividend policies that occur in this observation was $61 \%$.

Table 2. Descriptive statistics

\begin{tabular}{ccccc}
\hline Variable & Mean & Std. Dev. & Minimum & Maximum \\
\hline ROE & 5.76 & 47.10 & -134.20 & 350.22 \\
TOBIN'S-Q & 1.18 & 0.54 & 0.58 & 4.19 \\
RSPO & 0.63 & 0.49 & 0.00 & 1.00 \\
LIQ & 1.33 & 1.14 & 0.11 & 5.21 \\
DER & 0.71 & 5.56 & -45.96 & 10.16 \\
DP & 0.61 & 0.49 & 0.00 & 1.00 \\
OER & 22.12 & 1.09 & 19.86 & 24.50 \\
SIZE & 16.10 & 0.76 & 14.48 & 17.37 \\
AGE & 3.52 & 0.73 & 2.08 & 4.73 \\
\hline
\end{tabular}

The average CPO extraction rate reached $22.12 \%$. Firm size defined from the natural logarithm of total assets had a mean value of 16.10. Firm age on natural logarithms had an average value of 3.52. The correlation is performed to explain the strength and direction of the linear relationship between the independent variables. Moreover, correlation can detect multicollinearity problems assuming that the correlation value is at 0.8 or below $[47,48]$. Based on Table 3 , the correlation coefficient of each variable is below 0.8 . This indicates no multicollinearity problem so that each tested variable can be carried out for further analysis.

Table 3. Matrix correlation

\begin{tabular}{cccccccc}
\hline & RSPO & LIQ & DER & DIVP & OER & Size & Age \\
\hline RSPO & 1 & & & & & & \\
LIQ & 0.19 & 1 & & & & & \\
DER & -0.11 & 0.05 & 1 & & & & \\
DIVP & 0.40 & 0.48 & 0.05 & 1 & & & \\
OER & -0.03 & 0.24 & -0.01 & 0.04 & 1 & & \\
Size & 0.36 & 0.05 & -0.07 & 0.19 & -0.15 & 1 & \\
Age & 0.28 & 0.07 & -0.13 & -0.04 & -0.38 & 0.19 & 1 \\
\hline
\end{tabular}

The results of panel regression analysis are presented in Table 4 . The results of the first regression equation model with $\mathrm{ROE}$ as the dependent variable indicate that the model used as analysis interpretation is a fixed-effect model. This was obtained from the Hausman test, which obtained the chisquare statistical value of 16.97 ( $\mathrm{P}<0.05)$. Meanwhile, in the coefficient value analysis, there was no impact of RSPO certification on ROE, meaning that there was no difference in financial performance between certified companies and those that were not. Liquidity through the current ratio proxy had no impact on ROE. The capital structure through DER was found to have a negative impact on ROE. Moreover, companies that implement dividend policies or vice versa did not have ROE differences as financial performance indicators. The CPO extraction rate had a significant positive impact on ROE, but firm size did not have a significant impact. Firm age had a negative and significant impact on financial performance as proxied by ROE.

Table 4. Panel regression results

\begin{tabular}{ccccc}
\hline $\begin{array}{c}\text { First Panel: Dependent Variable: Return on Equity } \\
\text { Variable }\end{array}$ & Coefficient & Std. Error & t-Statistic & $\mathbf{p}>\mathbf{t}$ \\
\hline C & 25.50 & 196.49 & 0.13 & 0.90 \\
RSPO & -3.37 & 10.53 & -0.32 & 0.75 \\
LIQ & 2.23 & 2.82 & 0.79 & 0.43 \\
DER & -7.04 & 0.35 & -20.23 & 0.00 \\
DP & 4.34 & 5.49 & 0.79 & 0.43 \\
OER & 9.43 & 3.79 & 2.49 & 0.02 \\
SIZE & -1.40 & 9.17 & -0.15 & 0.88 \\
AGE & -57.98 & 23.14 & -2.50 & 0.02 \\
\hline N & 84 & & & \\
R-squared & 0.918 & & & \\
F-statistic & 35.252 & & & \\
Prob(F-statistic) & 0.000 & & & \\
\hline Second Panel: Dependent Variable: Tobin's-q & \\
Variable & Coefficient & Std. Error & t-Statistic & p>t \\
\hline C & 19.09 & 3.70 & 5.16 & 0.00 \\
RSPO & 0.02 & 0.20 & 0.11 & 0.91 \\
LIQ & 0.01 & 0.05 & 0.12 & 0.91 \\
DER & -0.00 & 0.01 & -0.03 & 0.98 \\
DP & -0.02 & 0.10 & -0.23 & 0.82 \\
OER & 0.05 & 0.07 & 0.66 & 0.51 \\
SIZE & -0.77 & 0.17 & -4.44 & 0.00 \\
AGE & -1.88 & 0.44 & -4.32 & 0.00 \\
\hline N & 84 & & & \\
R-squared & 0.779 & & & \\
F-statistic & 11.100 & & & \\
Prob(F-statistic) & 0.000 & & & \\
\hline \multicolumn{5}{c}{} \\
\hline
\end{tabular}


Based on the panel regression analysis on the second equation model with Tobin's-q as the dependent variable, it was found that the model used as the analysis interpretation was the fixed effect model. This was obtained from the Hausman test, which obtained the chi-square statistical value of 31.42 ( $\mathrm{P}<0.05)$. The coefficient analysis in the second regression equation showed that there was no difference in the market performance of companies that either follow RSPO certification or vice versa. This is similar to the variable liquidity findings; DER and CPO extraction rate does not significantly impact Tobin's-q. The dividend policy implemented by palm oil companies in Indonesia also did not create any differences in market performance. In contrast, it was found that firm size and firm age affected Tobin's-q.

This study reveals that Indonesia's palm oil companies that adopt RSPO certification do not have much better financial and market performance than companies that are not yet certified. This is inversely proportional to the findings of previous studies regarding the impact of following sustainable certification $[49,25]$. There are reasons related to this result, such as the condition of palm oil companies in Indonesia, which are allegedly unable to cover the costs of joining RSPO certification. It is because the cost for certification is higher for joining than expand the company manufacturer [50]. Previous findings revealed economic losses that allegedly came from the organization's certification and membership fees. It is also found that consumers are not yet willing to pay a premium price for sustainable palm oil [51].

The application of RSPO certification through a cost and benefit analysis resulted in the finding that there are financial performance losses for Indonesia's palm oil companies. The adoption of certification is only considered part of the company's responsibility towards the environment [50]. While there is a potential advantage of RSPO certification, it is the ability of palm oil companies to enter the market that requires certification [52]. Liquidity does not affect the financial performance and market performance of Indonesia palm oil companies. This is because the average liquidity value just reached the minimum value from ideal value ratio. The range of ideal value of current ratio is between of 1.2 and 2 [53]. DER has a negative and significant effect on financial performance. This is in line with the findings of previous studies $[33,34]$.

On the other hand, there is no effect of DER on-market performance. Palm oil companies are one of the agricultural industry sectors that require large financing at the beginning of their establishment, so that the capital structure of palm oil companies does not affect market performance. Dividend policy does not create differences in financial performance and market performance in palm oil companies in Indonesia. This contradicts with some previous research [37-39].

The CPO extraction rate affects financial performance, this is in line with previous research [26]. Conversely, the CPO extraction rate has no impact on market performance. This is because other fundamental factors are more considered by investors from the palm oil company [54]. The size of the palm oil company does not affect financial performance and vice versa. Firm size affects market performance. Palm oil companies concentrate on staple commodities that require large capital through a long-term investment process. Consequently, the big name of the palm oil company is not required to improve financial performance but merely to attract investors. Finally, the firm age is found to have a negative and significant impact on palm oil companies' financial and market performance. This is in line with the findings of previous studies [45, 46]. Both panel regression results have high $\mathrm{R}-\mathrm{Square}$ values. The first model on financial performance has a value of $91.8 \%$. The second model on market performance has a value of $77.9 \%$. This indicates that both regression models are good. The limitation of this study is exploration the RSPO certification on firm performance based on financial and market performance. It is because the other firm performance measurement such as operational performance has been carried out in other studies [29]

\section{CONCLUSION}

This research examines the impact of sustainable certification and the firm's internal factors on palm oil companies' financial and market performance in Indonesia. The findings on financial performance indicate that RSPO certification, liquidity, dividend policy, and firm size have no significant impact. On the other hand, the capital structure, the rate of CPO extraction, and the firm's age have a significant impact on the financial performance. Meanwhile, the findings that indicate that RSPO certification, liquidity, capital structure, dividend policy, and CPO extraction rates do not affect on market performance. Otherwise, firm size and age have a significant impact on market performance. The impact of RSPO certification for oil palm company referred to corporate sustainable responsibility for environment. It can be a reference for oil palm company on the impact of certification on firm performance.

This study has limitations, namely the use of analysis tools that are limited to panel regression analysis. Future research is expected to utilize other analytical techniques to determine the impact of sustainable certification on Indonesia's palm oil companies' performance. Therefore, it can also explore issues related to the impact of sustainable certification in other spheres, such as the trade of Indonesian palm oil in international markets. Finally, the future research must elaborate the expert from different background, especially from academician, government and communities.

This research provides insight into the impact of sustainable certification on the performance of palm oil companies in Indonesia from a financial and market perspective. In addition to investigating the impact of sustainable certification, this study also presents the impact of several internal factors on firm performance, such as liquidity, capital structure, dividend policy, CPO extraction rate, firm size, and firm age. This research can be used as a consideration and justification for palm oil company manager in Indonesia to adopt RSPO sustainability certification.

\section{ACKNOWLEDGMENT}

We would like to thank the Deputy for Strengthening Research and Development, Ministry of Research and Technology - National Research and Innovation Agency for providing the funding for our research. Similar remarks are also addressed to the School of Business of IPB University and the Faculty of Economics and Management of IPB University who have provided full support for this research. 


\section{REFERENCES}

[1] Bureau of Central Statistics. (2020). Crude Palm Oil Export. Jakarta.

[2] Suroso, A.I., Bakce, D., Firdaus, M. (2016). Impact of investment incentives on agribusiness and macroeconomy of Indonesia: A Computable General Equilibrium model. Journal of ISSAAS (International Society for Southeast Asian Agricultural Sciences), 22(1): 16-29.

[3] Maesaroh, S.S., Suroso, A.I., Pahan, I. (2018). Moratorium on oil palm: Ecological recovery or economic slowdown? Jurnal Aplikasi Manajemen, 16(1): 148-155. http://dx.doi.org/10.21776/ub.jam.2018.016.01.17

[4] Rifin, A. (2020). Assessing the impact of limiting Indonesian palm oil exports to the European Union. Journal of Economic Structures, 9(1): 26. https://doi.org/10.1186/s40008-020-00202-8

[5] Suroso, A.I., Ramadhan, A. (2014). Decision support system for agricultural appraisal in dryland areas. Advanced Science Letters, 20(10-11): 1980-1986. https://doi.org/10.1166/asl.2014.5687

[6] Suroso, A.I., Ramadhan, A. (2014). Structural path analysis of the influences from smallholder oil palm plantation toward household income: One aspect of eGovernment initative. Advanced Science Letters, 20(1): 352-356. https://doi.org/10.1166/asl.2014.5317

[7] Acosta, P., Curt, M.D. (2019). Understanding the expansion of oil palm cultivation: A case-study in Papua. Journal of Cleaner Production, 219: 199-216. https://doi.org/10.1016/j.jclepro.2019.02.029

[8] Vergura, D.T., Zerbini, C., Luceri, B. (2019). "Palm oil free" vs "sustainable palm oil": The impact of claims on consumer perception. British Food Journal, 121(9): 2027-2035. https://doi.org/10.1108/BFJ-01-2019-0020

[9] Saswattecha, K., Kroeze, C., Jawjit, W., Hein, L. (2015). Assessing the environmental impact of palm oil produced in Thailand. Journal of Cleaner Production, 100:

150-169. https://doi.org/10.1016/j.jclepro.2015.03.037

[10] Oosterveer, P. (2015). Promoting sustainable palm oil: Viewed from a global networks and flows perspective. Journal of Cleaner Production, 107: 146-153. https://doi.org/10.1016/j.jclepro.2014.01.019

[11] Rist, L., Feintrenie, L., Levang, P. (2010). The livelihood impacts of oil palm: smallholders in Indonesia. Biodiversity and Conservation, 19(4): 1009-1024 https://doi.org/10.1007/s10531-010-9815-z

[12] Verneau, F., La Barbera, F., Amato, M., Sodano, V. (2019). Consumers' concern towards palm oil consumption: An empirical study on attitudes and intention in Italy. British Food Journal, 121(9): 19821997. https://doi.org/10.1108/BFJ-10-2018-0659

[13] D'Antone, S., Spencer, R. (2015). Organising for sustainable palm oil consumption: A market-based approach. Consumption Markets \& Culture, 18(1): 55-71. https://doi.org/10.1080/10253866.2014.899217

[14] Santis, P., Albuquerque, A., Lizarelli, F. (2016). Do sustainable companies have a better financial performance? A study on Brazilian public companies. Journal of Cleaner Production, 133: 735-745. https://doi.org/10.1016/j.jclepro.2016.05.180

[15] Shahida, S., Hafizuddin-Syah, B.A.M., Fuad, S.H.
(2018). The effect of sustainability certification for export on operational profitability of Malaysian palm oil companies. Jurnal Ekonomi Malaysia, 52(2): 55-67. http://dx.doi.org/10.17576/JEM-2018-5202-5

[16] Hutabarat, S., Slingerland, M., Rietberg, P., Dries, L. (2018). Costs and benefits of certification of independent oil palm smallholders in Indonesia. International Food and Agribusiness Management Review, 21(6): 681-700. http://dx.doi.org/10.22004/ag.econ.274984

[17] Kadarusman, Y.B., Pramudya, E.P. (2019). The effects of India and China on the sustainability of palm oil production in Indonesia: Towards a better understanding of the dynamics of regional sustainability governance. Sustainable Development, 27(5): 898-909. https://doi.org/10.1002/sd.1949

[18] Taouab, O., Issor, Z. (2019). Firm performance: Definition and measurement models. European Scientific Journal, 15(1): 93-106. http://dx.doi.org/10.19044/esj.2019.v15n1p93

[19] Suroso, A I., Tandra, H., Syaukat, Y., Najib, M. (2021). The issue of decision making: sustainable and risk criteria. Decision Science Letters, 10(3): 241-246.

[20] Asghar, B., Wasim, A., Qazi, U., Rasool, A. (2020). Financial and non-financial practices driving sustainable firm performance: Evidence from banking sector of developing countries. Sustainability, 12(15): 6164. https://doi.org/10.3390/su12156164

[21] Okafor, G. (2017). The determinants of firm performance and bribery: Evidence from manufacturing firms in Nigeria. International Economic Journal, 31(4): 647-669. https://doi.org/10.1080/10168737.2017.1380678

[22] RSPO. (2020). About. Retrieved July 18, 2020, from About website: https://rspo.org/about.

[23] Hellmeister, A., Richins, H. (2019). Green to gold: Beneficial impacts of sustainability certification and practice on tour enterprise performance. Sustainability, 11(3): 709. https://doi.org/10.3390/su11030709

[24] Feng, Y., Lai, K.H., Zhu, Q. (2020). Legitimacy in operations: How sustainability certification announcements by Chinese listed enterprises influence their market value? International Journal of Production Economics, 224: 107563. https://doi.org/10.1016/j.ijpe.2019.107563

[25] Hafizuddin-Syah, B.A.M., Shahida, S., Fuad, S.H. (2018). Sustainability certifications and financial profitability: An analysis on palm oil companies in Malaysia. Jurnal Pengurusan (UKM Journal of Management), 54: 143-154. https://doi.org/10.17576/pengurusan-2018-54-12

[26] Tey, Y.S., Brindal, M., Darham, S., Sidique, S.F.A., Djama, M. (2020). Early mover advantage in Roundtable on Sustainable Palm Oil certification: A panel evidence of plantation companies. Journal of Cleaner Production, 252: 119775. https://doi.org/10.1016/j.jclepro.2019.119775

[27] Matar, A., Eneizan, B.M. (2018). Determinants of financial performance in the industrial firms: Evidence from Jordan. Asian Journal of Agricultural Extension, Economics \& Sociology, 22(1): 1-10. https://doi.org/10.9734/AJAEES/2018/37476

[28] Amene, T.B., Alemu, G.A. (2019). Determinants of financial performance in private banks: A case in Ethiopia. African Journal of Business Management, 13(9): 
https://doi.org/10.5897/AJBM2019.8771

[29] Suroso, A.I., Tandra, H., Najib, M., Syaukat, Y. (2020). Firm performance factors and efficiency of Indonesian palm oil companies. Jurnal Manajemen \& Agribisnis, 17(3): 227-227. https://doi.org/10.17358/jma.17.3.227

[30] Mota, J.H., Moreira, A.C. (2017). Determinants of the capital structure of Portuguese firms with investments in Angola. South African Journal of Economic and Management $\quad$ Sciences, $20(1)$ : 1-11. https://hdl.handle.net/10520/EJC-5a3f118ea

[31] Muritala, T.A. (2012). An empirical analysis of capital structure on firms' performance in Nigeria. International Journal of Advances in Management and Economics, 1(5): 116-124.

[32] Detthamrong, U., Chancharat, N., Vithessonthi, C. (2017). Corporate governance, capital structure and firm performance: Evidence from Thailand. Research in International Business and Finance, 42: 689-709. https://doi.org/10.1016/j.ribaf.2017.07.011

[33] Al-Duais, F. (2016). An empirical study on capital structure and corporate performance of Chinese listed companies. Journal of Commerce \& Accounting Research, 5(3): 18-21.

[34] Li, K., Niskanen, J., Niskanen, M. (2018). Capital structure and firm performance in European SMEs: Does credit risk make a difference? Managerial Finance, 45(5): 582-601. https://doi.org/10.1108/MF-01-2017-0018

[35] Al-Kuwari, D. (2009). Determinants of the dividend policy of companies listed on emerging stock exchanges: the case of the Gulf Cooperation Council (GCC) countries. Global Economy \& Finance Journal, 2(2): 3863.

[36] Amidu, M. (2007). How does dividend policy affect performance of the firm on Ghana stock Exchange. Investment management and financial innovations, 4(2): 103-112.

[37] Farrukh, K., Irshad, S., Shams Khakwani, M., Ishaque, S., Ansari, N.Y. (2017). Impact of dividend policy on shareholders wealth and firm performance in Pakistan. Cogent Business \& Management, 4(1): 1408208. https://doi.org/10.1080/23311975.2017.1408208

[38] Khan, M.N., Nadeem, B., Islam, F., Salman, M., Gill, H.M.I.S. (2016). Impact of dividend policy on firm performance: An empirical evidence from Pakistan Stock Exchange. American Journal of Economics, Finance and Management, 2(4): 28-34.

[39] Paminto, A., Setyadi, D., Sinaga, J. (2016). The effect of capital structure, firm growth and dividend policy on profitability and firm value of the oil palm plantation companies in Indonesia. European Journal of Business and Management, 8(33): 123-134.

[40] Utomo, M.N., Wahyudi, S., Muharam, H., Taolin, M.L. (2018). Strategy to improve firm performance through operational efficiency commitment to environmental friendliness: Evidence from Indonesia. Organizations and Markets in Emerging Economies, 9(1): 62-85. https://doi.org/10.15388/omee.2018.10.00004

[41] Abor, J., Biekpe, N. (2009). How do we explain the capital structure of SMEs in sub-Saharan Africa?
Evidence from Ghana. Journal of Economic Studies, 36(1): 83-97. https://doi.org/10.1108/01443580910923812

[42] Lazăr, S. (2016). Determinants of firm performance: evidence from Romanian listed companies. Review of Economic and Business Studies, 9(1): 53-69. https://doi.org/10.1515/rebs-2016-0025

[43] Coad, A., Holm, J.R., Krafft, J., Quatraro, F. (2018). Firm age and performance. Journal of Evolutionary Economics, 28(1): 1-11. https://doi.org/10.1007/s00191017-0532-6

[44] Akben Selçuk, E. (2016). Does firm age affect profitability? Evidence from Turkey. International Journal of Economic Sciences, 3(5): 1-9. https://doi.org/10.20472/ES.2016.5.3.001

[45] Pervan, M., Pervan, I., Ćurak, M. (2017). The influence of age on firm performance: evidence from the Croatian food industry. Journal of Eastern Europe Research in Business and Economics, 2017(1): 618681. https://doi.org/10.5171/2017.618681

[46] Vu, T.H., Nguyen, V.D., Ho, M.T., Vuong, Q.H. (2019). Determinants of Vietnamese listed firm performance: Competition, wage, CEO, firm size, age, and international trade. Journal of Risk and Financial Management, 12(2): https://doi.org/10.3390/jrfm12020062

[47] Gujarati, D.N., Porter, D.C. (2009). Basic Econometrics (5th ed.). In Basic Econometrics.

[48] Tay, R. (2017). Correlation, variance inflation and multicollinearity in regression model. Journal of the Eastern Asia Society for Transportation Studies, 12: 2006-2015. https://doi.org/10.11175/easts.12.2006

[49] Gómez-Bezares, F., Przychodzen, W., Przychodzen, J. (2017). Bridging the gap: How sustainable development can help companies create shareholder value and improve financial performance. Business Ethics: A $\begin{array}{lll}\text { European } & \text { Review, } & \text { 26(1): }\end{array}$ https://doi.org/10.1111/beer.12135

[50] Salman, F., Najib, M., Djohar, S. (2017). Cost and benefit analysis of RSPO certification (Case study in PT BCA oil palm plantation in Papua). Indonesian Journal of Business and Entrepreneurship (IJBE), 3(3): 219-219. https://doi.org/10.17358/ijbe.3.3.219

[51] Yusof, B., Yew, F. (2016). The burden of RSPO certification costs on Malaysian palm oil industry and national economy. Journal of Oil Palm, Environment \& Health, 7: 19-27.

[52] Richardson, B. (2015). Making a market for sustainability: The commodification of certified palm oil. New Political Economy, 20(4): 545-568. https://doi.org/10.1080/13563467.2014.923829

[53] Sukiennik, M. (2012). The analysis of mining company liquidity indicators. AGH Journal of Mining and Geoengineering, 36(3): 339-344.

[54] Petrusheva, N., Jordanoski, I. (2016). Comparative analysis between the fundamental and technical analysis of stocks. Journal of Process Management. New Technologies, 4(2): 26-31. 